\title{
Molecular Identification of Endophytic Fungi Isolated from Medicinal Plant
}

\author{
Pooja Singh 1(D), Angkita Sharma 1(D), Manobjyoti Bordoloi ${ }^{2}$ (D), Shoma Paul Nandi 1,*(D) \\ Amity Institute of Biotechnology, Amity University, Noida-201313, Uttar Pradesh \\ 2 Natural Products Chemistry Division, CSIR-North East Institute of Science and Technology (NEIST); Jorhat-785013, \\ Assam \\ * Correspondence: spaul@amity.edu;
}

Scopus Author ID 36731454500

Received: 10.04.2020; Revised: 5.05.2020; Accepted: 8.05.2020; Published: 13.05.2020

\begin{abstract}
Endophytes are microorganisms that colonize the tissues of live host plants usually showing no apparent symptoms. These endophytes, both bacteria and fungus, can produce a variety of secondary metabolites having a wide range of essential properties. Thus, they can be used for various medicinal, environmental and agronomic purposes. Argemone mexicana, a plant of the family Papaveraceae is widespread across India, and blooms in the month of March. The study was carried out to isolate endophytic fungus living in the shoot and root areas of A. mexicana from Northeast India, and to identify and characterize these endophytes. A total of 20 types of fungal species were isolated from both the root and shoot parts of the plant. Endophytes were identified by 18SrDNA sequencing using ITS1 and ITS4 primers. Genomic DNA was isolated using Cetyl trimethyl ammonium bromide method of the endophytes. The endophytic fungi were identified as belonging to Aspergillus and Penicillium sps by using sequence analysis of the internal transcribed spacer region and Basic local alignment search tool. Aspergillus oryzaem A. niger, and A. flavus showed $100 \%$ relative abundance in root and shoot. A. versicolor, A. sydowii, Penicillium chrysogenum were found in root only and A. striatus, A. tubingensis, Emericella qinqixianii and E. striata were found in the shoot of A. mexicana.
\end{abstract}

Keywords: Medicinal plant; fungal endophytes; molecular characterization; Aspergillus; Penicillium; 18SrDNA; Rose Bengal Base Agar.

(C) 2020 by the authors. This article is an open access article distributed under the terms and conditions of the Creative Commons Attribution (CC BY) license (https://creativecommons.org/licenses/by/4.0/).

\section{Introduction}

Endophytes (fungal and bacterial) thrive in the intercellular spaces, cortex, epidermis, endodermis and vascular bundles of the host plant tissues and also inside the cells (symplasts) which causes no visible damage [1]. Thus, an association between endophytes and their host plants is considered as a symbiosis. Plants having endophytes have advantages such as defenses against pathogens and herbivores, plant growth promotion by helping in the production of growth hormones and production of secondary metabolites [2-3]. Moreover, the endophyte increases to improved resource availability [4].

The Papaveraceae family of the plant kingdom includes consists around 775 species in 42 genera. Argemone Mexicana is considered an important commercial property, which mainly concerns medical applications including rheumatism, tumors, inflammations, skin diseases, leprosy, jaundice microbial infections, etc [5]. It is commonly known as 'Mexican prickly poppy' or 'Satyanashi'. It is an herb with yellow flower. The height differs between 0.3 to 
$0.12 \mathrm{~m}$ long. Its leaves are sessile, sinuately, semi-amplexicaul, spiny on margins and pinnatified. Various plant parts of A. mexicana have medicinal properties and also reported to have potent narcotic and emetic abilities. One of the added advantages of using this plant for the study is its easy availability, along with its tolerance to drought and poor soil. This plant, originally from Mexico, is now naturalized in many places over the globe; it is found by roadsides and fields across India and many parts of the USA. Plant's metabolism, colonizing symbiotic, or even parasitic microbes contribute significantly to secondary metabolite production and thus aid to medicinal, agronomic and environmental properties of these plants. Most of the important terpenoids, tannins, sterols, alkaloids, etc are found in it [6].

Endophytic fungi are found mostly in terrestrial habitats that have vital economical and ecological roles in their host plant communities. They have complex relations with their host plants and also talk with other endophytes that live in the same plant [7]. Endophytes have been known as a rich source for producing secondary metabolites. Certain endophytes have evolved to mimic plant defense compounds and secondary metabolites [7]. Such secondary metabolites have great chemical variability and uncountable pharmaceutical and biotechnological properties. They have antibacterial, antiviral and antifungal properties. Apart from its antimicrobial properties, certain secondary metabolite is immune-stimulating compounds including phomoxanthone $\mathrm{A}$, a compound known to increase the quantity macrophages, activated murine $\mathrm{T}$ lymphocytes, Jurkat $\mathrm{T}$ lymphocytes and Natural Killer (NK) cells [8]. Additionally, endophytic fungal secondary metabolites showed the presence of glucosides, tannins, and flavonoids that increases neutrophil phagocytic activity in human beings.

The aim of this research was to perform an identification of the taxonomy and to determine the phylogenetic relatedness and ecological parameters of the endophytic fungal communities, which colonize the root and shoot of $A$. Mexicana plant.

\section{Materials and Methods}

\subsection{Sample collection site.}

A. mexicana plants were collected from Brahmaputra bank, Assam, India. Samples were aseptically transferred into separate zipped sterile polythene bags and brought back to the laboratory at room temperature [9]. The samples were then washed using tap water to remove debris and kept at $4^{\circ} \mathrm{C}$ before use.

\subsection{Isolation of endophytes.}

Endophytes were isolated from A. mexicana plant using standard protocol. Surface sterilization was done with $70 \%$ ethanol, sterile water and $4 \%$ sodium hypochlorite solution. The plant roots were chopped into segments of $1-2 \mathrm{~cm}$ in length. This whole procedure was carried out in laminar air flow. Plant segments were rinsed with $75 \%$ ethanol for 1 min and then with $4 \%$ sodium hypochlorite solution for $10 \mathrm{~min}$. This was followed by immersing the segments in $75 \%$ ethanol for $1 \mathrm{~min}$. Finally, all the plant segments were rinsed thrice with sterilized distilled water and were allowed to air dry. The roots were then crushed by sterile mortar \& pestle in $1 \mathrm{ml}$ sterile distilled water and the $100 \mu \mathrm{l}$ of the plant extract was added on the Rose Bengal Base Agar (RBBA) media plates (containing $100 \mu \mathrm{g} / \mathrm{mL}$ streptomycin). The plates were incubated at $28^{\circ} \mathrm{C}$ for one week [10]. 
After visualization of fungus colonies on the mother culture plate, the hyphal tip of the fungus was collected and transferred on separate RBBA media plate and incubated at $28^{\circ} \mathrm{C}$, and this process was repeated till the culture is pure obtain a pure culture.

\subsection{DNA isolation.}

DNA isolation of the fungal isolates was done using the Cetyl trimethyl ammonium bromide (CTAB) method. After DNA pellet obtained was washed with ethanol $(75 \%)$ and was centrifuged at $10,000 \mathrm{rpm}$ for $10 \mathrm{~min}$ at $4^{\circ} \mathrm{C}$, The DNA pellet was dried and dissolved in 200 $\mu 1$ of distilled water.

DNA isolation of the fungal isolates was done using the Cetyl trimethyl ammonium bromide (CTAB) method of DNA isolation. Pestle and mortars were pre-cooled at $4{ }^{\circ} \mathrm{C}$ and $1 \mathrm{gm}$ of sample was submerged in alcohol (absolute) for 30minute. After that alcohol was allowed to evaporate. The $5 \mathrm{gm}$ mycelium was ground to a fine powder with sterile mortar \& pestle and transfer to a plastic sterile tube. The pre-warmed isolation buffer $(10 \mathrm{ml})$ was added to fine powder and mixed properly then it was incubated for $60 \mathrm{~min}$ at $65^{\circ} \mathrm{C}$ with occasional stirring. After incubation, tubes were left at room temperature for a few mins for cooling. Ten $\mathrm{ml}$ of chloroform: isoamyl alcohol (24: 1) was added to mixture and mixed properly. Centrifuge was done at $10,000 \mathrm{rpm}$ for $20 \mathrm{mins}$ at room temperature $\left(24^{\circ} \mathrm{C}\right)$. After centrifugation, the supernatant was transferred to fresh tube. Ice- cold isopropanol (0.6 volume) and $3 \mathrm{M}$ sodium acetate $\left(0.1\right.$ volume) were added to the aqueous phase and incubated at $-20^{\circ} \mathrm{C}$ for 30 mins. Reaction mixture was centrifuged at $10,000 \mathrm{rpm}$ for $10 \mathrm{~min}$ at $4^{\circ} \mathrm{C}$ after incubation, and then the aqueous phase was discarded. DNA pellet was obtained and was washed with ethanol (75\%) and was centrifuged at $10,000 \mathrm{rpm}$ for $10 \mathrm{~min}$ at $4^{\circ} \mathrm{C}$, the aqueous phase was discarded. The DNA pellet was dried and dissolved in $200 \mu \mathrm{l}$ of distilled water.

\subsection{PCR amplification.}

Fungal DNA was multiplied using 18s rRNA gene primers [11]. ITS1F (5'TCCGTAGGTGAACCTGCGG) primer and ITS4R (5'-TCCTCCGCTTATTGATATGC) primer [11]. The amplified genes were sequenced by a commercial company with a Chromous Biotech Pvt. Ltd., Bangalore, India. The obtained sequence data were aligned by using the BLAST software (http://blast.ncbi.nlm.nih.gov) algorithm at NCBI.

\section{Results and Discussion}

The total 8 types of endophytic fungi from the root and 12 types from the shoot were isolated from A. mexicana Aspergillus sp., Penicillium sp. (Fig.1) and Emericella sp. were identified (Fig. 1). The strains of fungal isolates found in A. mexicana plant roots and shoots are given in Table 1 . The relative abundance of the fungal strains in both the root and shoot parts of the plant are shown in Fig. 2 and Fig. 3.

Neighbor-Joining method was used to check the evolutionary history [12]. The bootstrap tree was inferred from a 1000 replicates [13]. Those branches that correspond to partitions that are repeated in less than $50 \%$ replicates are collapsed. Maximum Composite Likelihood method was used to check the evolutionary distances [14]. This analysis involved as many as nine nucleotide sequences. The evolutionary analyses were conducted in MEGA X [15], are shown in Fig. 4 and Fig. 5. 


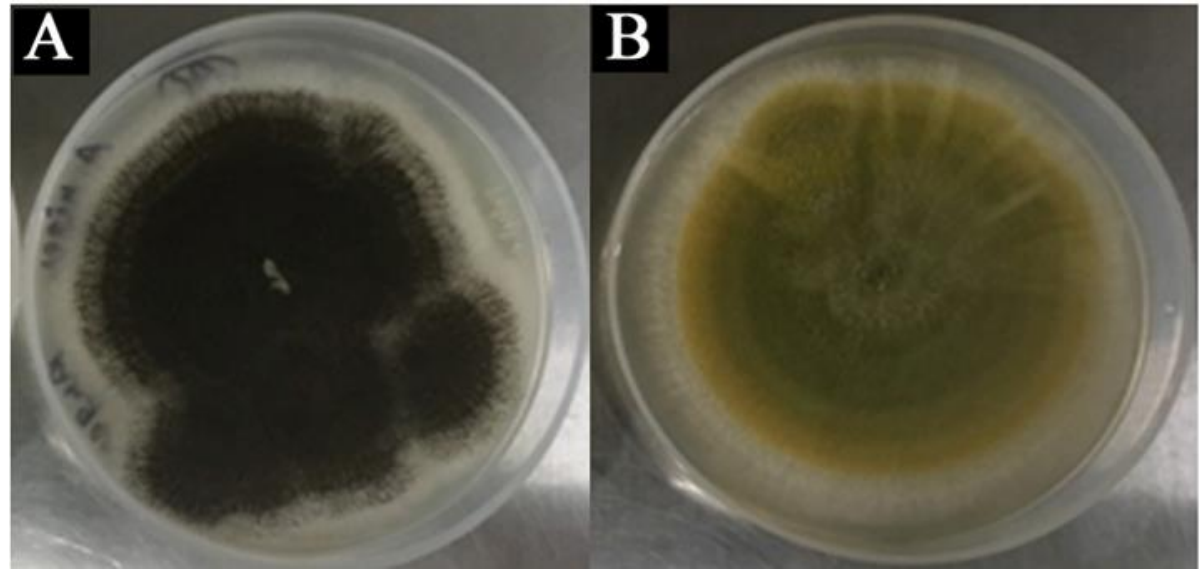

Figure 1. Pure endophytic fungus from root. A. Aspergillus niger, B. Aspergillus flavus were Isolated from A.mexicana

Table 1. Following are the endophytic fungi isolated from root and shoot of A.mexicana plant.

\begin{tabular}{|c|c|c|c|c|c|c|}
\hline S. No. & $\begin{array}{l}\text { Culture } \\
\text { ID }\end{array}$ & $\begin{array}{l}\text { Fungal species with } \\
\text { Greatest similarity }\end{array}$ & $\begin{array}{l}\text { Tissue } \\
\text { Plant part }\end{array}$ & $\begin{array}{l}\text { Accession } \\
\text { Number with } \\
\text { greatest } \\
\text { similarity }\end{array}$ & $\begin{array}{l}\text { Maximum } \\
\text { Identity }(\%)\end{array}$ & $\begin{array}{l}\text { New Accession } \\
\text { number } \\
\text { obtained from } \\
\text { NCBI }\end{array}$ \\
\hline 1. & ARF1 & Aspergillus niger & Root & MN704696.1 & $98.82 \%$ & MT322425 \\
\hline 2. & ARF2 & Aspergillus flavus & Root & $\underline{\mathrm{KY}} 022753.1$ & $100.00 \%$ & - \\
\hline 3. & ARF3 & Aspergillus versicolor & Root & MF576084.1 & $100.00 \%$ & - \\
\hline 4. & ARF4 & Aspergillus sydowii & Root & $\underline{\text { MG799216.1 }}$ & $100.00 \%$ & - \\
\hline 5. & ARF5 & Aspergillus sydowii & Root & MN658458.1 & $100.00 \%$ & - \\
\hline 6. & ARF6 & Aspergillus oryzae & Root & MH345954.1 & $100.00 \%$ & - \\
\hline 7. & ARF7 & Penicillium chrysogenum & Root & MK841451.1 & $100.00 \%$ & - \\
\hline 8. & ARF8 & Penicillium chrysogenum & Root & KR233468.1 & $99.82 \%$ & MT322426 \\
\hline 9. & ASF1 & Aspergillus niger & Shoot & MN704691.1 & $100.00 \%$ & - \\
\hline 10. & ASF2 & Aspergillus niger & Shoot & MF379661.1 & $100.00 \%$ & - \\
\hline 11. & ASF3 & Aspergillus oryzae & Shoot & MT071405.1 & $100.00 \%$ & - \\
\hline 12. & ASF4 & Aspergillus flavus & Shoot & MN565937.1 & $93.33 \%$ & MT322245 \\
\hline 13. & ASF5 & Aspergillus flavus & Shoot & MN238861.1 & $100.00 \%$ & - \\
\hline 14. & ASF6 & Aspergillus flavus & Shoot & MN031603.1 & $99.46 \%$ & MT322246 \\
\hline 15. & ASF7 & Aspergillus oryzae & Shoot & $\underline{\mathrm{MH} 345954.1}$ & $99.46 \%$ & MT322247 \\
\hline 16. & ASF8 & Aspergillus striatus & Shoot & KU866614.1 & $99.62 \%$ & MT322248 \\
\hline 17. & ASF9 & Aspergillus tubingensis & Shoot & $\underline{\text { GU134883.1 }}$ & $99.82 \%$ & MT322249 \\
\hline 18. & ASF10 & Aspergillus tubingensis & Shoot & MH055392.1 & $99.82 \%$ & MT322427 \\
\hline 19. & ASF11 & Emericella qinqixianii & Shoot & КС692210.1 & $99.81 \%$ & MT322250 \\
\hline 20. & ASF12 & Emericella striata & Shoot & $\underline{\mathrm{AB} 248980.1}$ & $99.44 \%$ & MT322251 \\
\hline
\end{tabular}
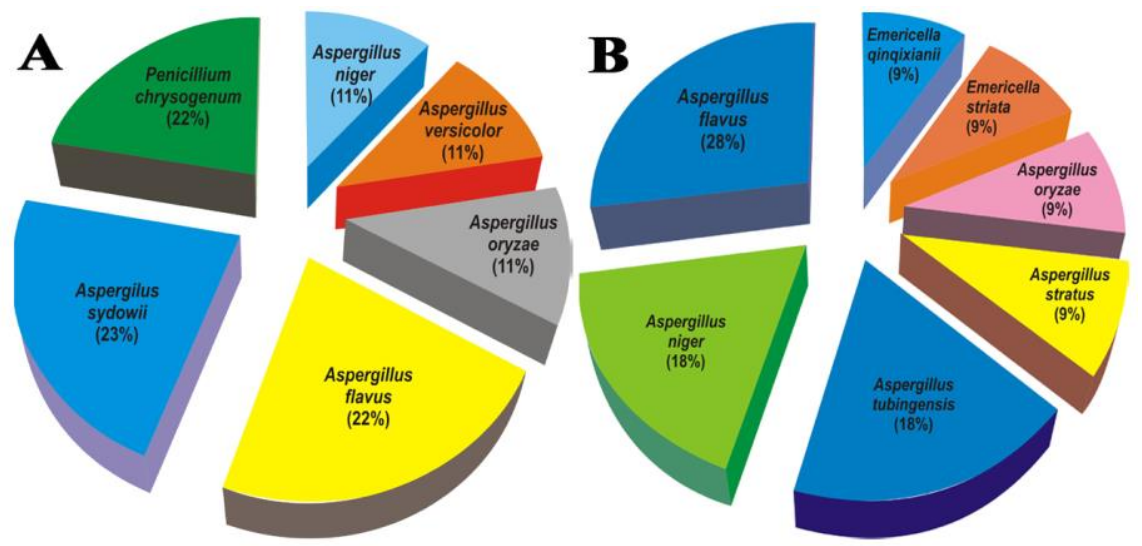

Figure 2: Abundance of each genus and species identified among fungal endophytes from $A$. mexicana plant. , A- in the root of plant; B- in the shoot of plant 


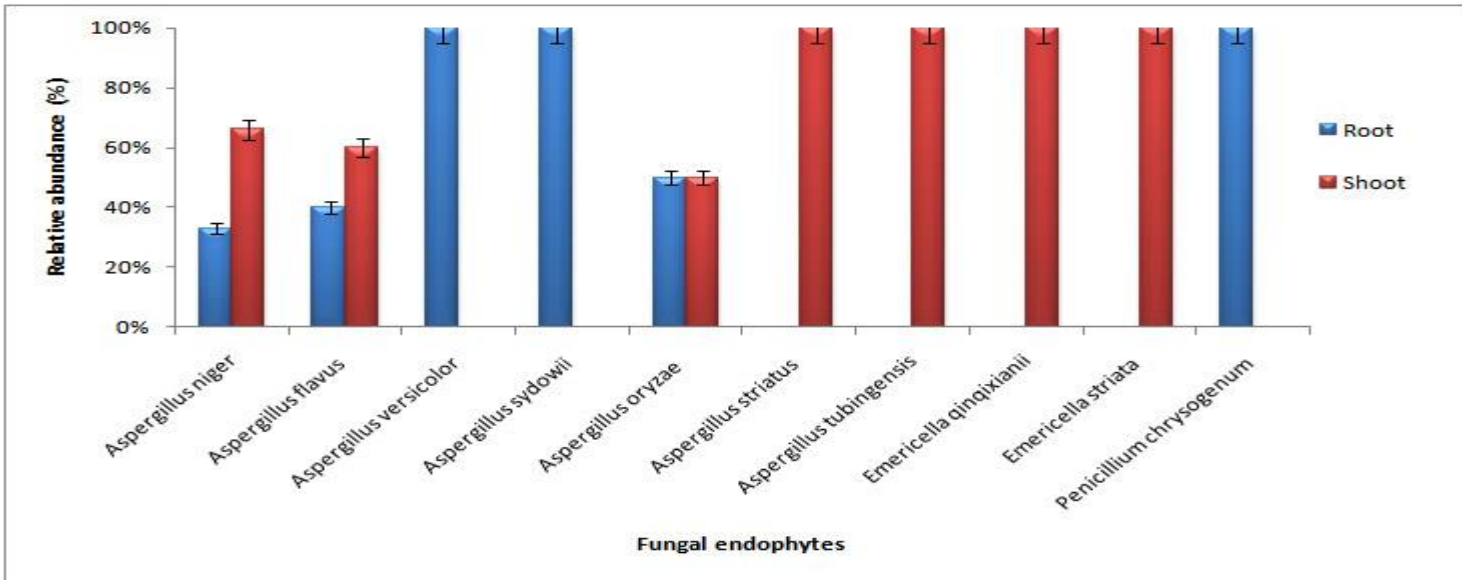

Figure 3: Relative abundance of endophytic fungal isolates of A. mexicana The bars. Error bar represents error with percentage.

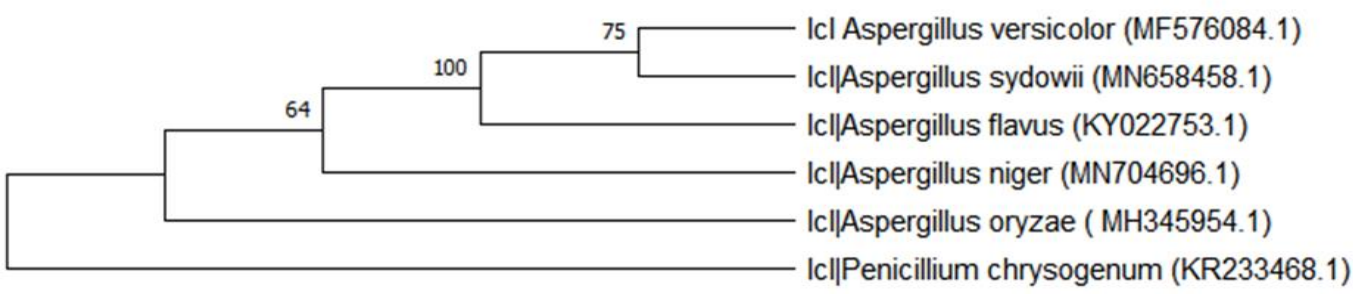

Figure 4: Evolutionary relationships of taxa of fungal endophytes from root of A. mexicana.

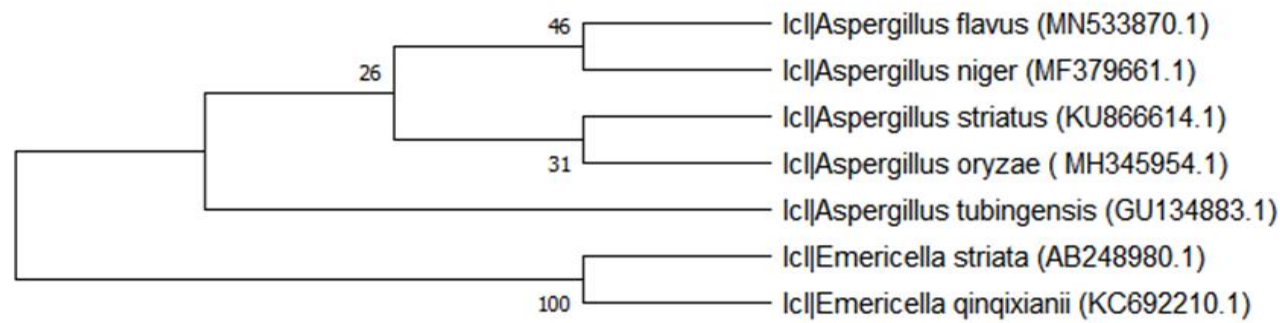

Figure 5: Evolutionary relationships of taxa of fungal endophytes from shoot of A.exicana.

The major fungal secondary metabolites can be grouped in different classes, nonribosomal peptides, polyketides, alkaloids, terpenes, and more recently, ribosomal peptides. The ascomycetous fungi Aspergillus genus, has over 330 different species, which represent some of the most important and common fungi available in the environment. Aspergillus species belong to one of the most potent fungi that are capable of biosynthesizing a huge range of both primary and secondary metabolites [16].

Penicillium genus is filamentous fungus and found commonly in soil habitats, plants [17]. It is reported in literature that it can produce important secondary metabolites, including steroid and terpenoids, esters, quinones, polyketides, alkaloids, peptides and many other unidentified compounds [18-21]. These secondary metabolites have antifungal agent [22-24], antibacterials [21, 23-26], anticancer agent [27-28], antioxidant, antiviral [29], antidiabetic [30], anti-Alzheimer's disease [31], it has been used for epilepsy and toxocariasis treatment [32], -leishmanial and -inflammatory Agents [33].

The host plant, A. mexicana plant has various medicinal properties attributed to its primary and secondary metabolites, which include flavonoids, alkaloids, saponins, glycosides, phenol, lignins, tannins and sterols [34]. These compounds are highly effective against various 
diseases. An extensive range of phytocompounds and fatty acids identified from the plant shows antifungal, antibacterial, antimycotic and anti-inflammatory activities [31].

This study focuses on the diversity of endophytic fungi in different parts of A. mexicana plant and also to understand the symbiosis between the plant and its endophytes concerning their secondary metabolite production.

\section{Conclusions}

The study offers an insight into the diversity of endophytic fungal population isolated from A. mexicana. The data obtained shows twenty endophytic fungi isolated from both the root and shoot parts of the plant. The molecular characterization shows the fungal strains mostly belonging to two genus Aspergillus and Penicillium species. Antimicrobial activity of the fungal isolates is on progress.

\section{Funding}

This research received fund from NE-DBT (Application No: AGRI/2015/48).

\section{Acknowledgments}

The authors are thankful to Retd.Scientist from ICAR Prof. Amithabh Bandopadhyay for his guidance.

\section{Conflicts of Interest}

The authors declare no conflict of interest.

\section{References}

1. Saikkonen, K.; Faeth, S.H.; Helander, M.; Sullivan, T.J. FUNGAL ENDOPHYTES: A Continuum of Interactions with Host Plants. Annual Review of Ecology and Systematics 1998, 29, 319-343, https://doi.org/10.1146/annurev.ecolsys.29.1.319.

2. Schulz, B.; Boyle, C. What are Endophytes? In: Microbial Root Endophytes. Schulz, B.J.E., Boyle, C.J.C., Sieber, T.N., Eds. Springer Berlin Heidelberg: Berlin, Heidelberg, Volume 9, 2006; pp. 1-13, https://doi.org/10.1007/3-540-33526-9_1.

3. Yim, G.; Wang, H.H.; Davies, J., Antibiotics as signaling molecules. Philos. Trans. Soc. B. 2007, 362, 11951200, https://doi.org/10.1098/rstb.2007.2044.

4. Clay, K. Fungal Endophytes of Grasses: A Defensive Mutualism between Plants and Fungi. Ecology 1988, 69, 10-16, https://doi.org/10.2307/1943155.

5. Sharma, J.; Gairola, S.; Gaur, R.D.; Painuli, R.M. The treatment of jaundice with medicinal plants in indigenous communities of the Sub-Himalayan region of Uttarakhand, India. Journal of Ethnopharmacology 2012, 143, 262-291, https://doi.org/10.1016/j.jep.2012.06.034.

6. Takahashi, J.; Sande, D.; Lima, G.; Moura, M.; Nogueira, S.L.; Matheus, T. Fungal Metabolites as Promising New Drug Leads for the Treatment of Alzheimer's Disease. Studies in Natural Products Chemistry. Volume 62, 2019; pp. 1-39, https://doi.org/10.1016/B978-0-444-64185-4.00001-0.

7. Kusari, S.; Hertweck, C.; Spiteller, M. Chemical Ecology of Endophytic Fungi: Origins of Secondary Metabolites. Chemistry \& Biology 2012, 19, 792-798, https://doi.org/10.1016/j.chembiol.2012.06.004.

8. Rönsberg, D.; Debbab, A.; Mándi, A.; Vasylyeva, V.; Böhler, P.; Stork, B.; Engelke, L.; Hamacher, A.; Sawadogo, R.; Diederich, M.; Wray, V.; Lin, W.; Kassack, M.U.; Janiak, C.; Scheu, S.; Wesselborg, S.; Kurtán, T.; Aly, A.H.; Proksch, P. Pro-Apoptotic and Immunostimulatory Tetrahydroxanthone Dimers from the Endophytic Fungus Phomopsis longicolla. The Journal of Organic Chemistry 2013, 78, 12409-12425, https://doi.org/10.1021/jo402066b.

9. Ratnaweera, P.B.; de Silva, E.D.; Williams, D.E.; Andersen, R.J. Antimicrobial activities of endophytic fungi obtained from the arid zone invasive plant Opuntia dillenii and the isolation of equisetin, from endophytic Fusarium sp. BMC Complem Altern M. 2015, 15, 220, https://dx.doi.org/10.14288/1.0074648. 
10. Compant, S.; Mitter, B.; Colli-Mull, J.G.; Gangl, H.; Sessitsch, A. Endophytes of Grapevine Flowers, Berries, and Seeds: Identification of Cultivable Bacteria, Comparison with Other Plant Parts, and Visualization of Niches of Colonization. Microbial Ecology 2011, 62, 188-197, https://doi.org/10.1007/s00248-011-9883-y.

11. Manter, D.K.; Vivanco, J.M. Use of the ITS primers, ITS1F and ITS4, to characterize fungal abundance and diversity in mixed-template samples by qPCR and length heterogeneity analysis. Journal of Microbiological Methods 2007, 71, 7-14, https://doi.org/10.1016/j.mimet.2007.06.016.

12. Saitou, N.; Nei, M. The neighbor-joining method: a new method for reconstructing phylogenetic trees. Molecular Biology and Evolution 1987, 4, 406-425, https://doi.org/10.1093/oxfordjournals.molbev.a040454.

13. Felsenstein, J. Confidence limits on phylogenies: An approach using the bootstrap. Evolution 1985, 39, 783791, https://doi.org/10.1111/j.1558-5646.1985.tb00420.x.

14. Tamura, K.; Nei, M.; Kumar, S. Prospects for inferring very large phylogenies by using the neighbor-joining method. Proceedings of the National Academy of Sciences USA 2004, 101, 11030-11035, https://doi.org/10.1073/pnas.0404206101.

15. Kumar, S.; Stecher, G.; Li, M.; Knyaz, C.; Tamura, K. MEGA X: Molecular Evolutionary Genetics Analysis across computing platforms. Mol Biol Evol 2018, 35, 1547-1549, https://doi.org/10.1093/molbev/msy096.

16. Soltani, J. Secondary metabolite diversity of the genus Aspergillus: recent advances. In: Book New and Future Developments in Microbial Biotechnology and Bioengineering: Aspergillus System Properties and Applications. ed. Gupta, V.K. (Amsterdam: Elsevier B.V.) 2016; 275-292, https://doi.org/10.1016/B978-0-444-635051.00035-X.

17. Visagie, C.M.; Houbraken, J.; J.C.Frisvad, J.C.; Hong, S.B.; Klaassen C.H.W.; Perrone, G.; Seifert, K.A.; J.Varga, Yaguchi, J.T.; R.A.Samson, R.A. Identification and nomenclature of the genus Penicillium. Stud Mycol 2014, 78, 343-371, https://doi.org/10.1016/j.simyco.2014.09.001.

18. Nicoletti, R.; Trincone, A. Bioactive Compounds Produced by Strains of Penicillium and Talaromyces of Marine Origin. Mar. Drugs 2016, 14, https://doi.org/10.3390/md14020037.

19. Petit, P.; Lucas, E.M.F.; Abreu, L.M.; Pfenning, L.H.; Takahashi, J.A. Novel antimicrobial secondary metabolites from a Penicillium sp. Isolated from Brazilian cerrado soil. Elect. J. Biotechnol. 2009, 12, 8-9, https://doi.org/10.2225/vol12-issue4-fulltext-9.

20. Gao, S.S.; Li, X.M.; Du, F.Y.; Li, C.S.; Proksch, P.; Wang, B.G. 2010. Secondary metabolites from a marinederived endophytic fungus Penicillium chrysogenum QEN-24S. Mar. Drugs 2010, 9, 59-70, https://doi.org/10.3390/md9010059.

21.Zhelifonova, V.P.; Antipova, T.V.; Kozlovsky, A.G. 2010. Secondary metabolites in taxonomy of the Penicillium fungi. Microbiology 2010, 79, 277-286, https://doi.org/10.1134/S002626171003001X.

22. Yu, J.; Wu, Y.; He, Z.; Li, M.; Zhu, K.; Gao, B. Diversity and Antifungal Activity of Endophytic Fungi Associated with Camellia oleifera. Mycobiol 2018, 46, 85-91, https://doi.org/10.1080/12298093.2018.1454008. 23. Hastuti, U.S.; Rahmawati, D.; Sari, R.Y.; Fitri, R.D.; Al Asna, P.M. Antimicrobial activity of endophytic fungi isolated from a medicinal plant, Hedychium acuminatum Roscoe. AIP Conference Proceedings 2019, https://doi.org/10.1063/1.5061895.

24. Chi, W.C.; Pang, K.L.; Chen, W.L.; Wang, G.J.; Lee, T.H. Antimicrobial and iNOS inhibitory activities of the endophytic fungi isolated from the mangrove plant Acanthus ilicifolius var. xiamenensis. Bot Stud 2019, 60, https://doi.org/10.1186/s40529-019-0252-3.

25. Manganyi, M.C.; Regnier, T.; Tchatchouang, C.-D.K.; Bezuidenhout, C.C.; Ateba, C.N. Antibacterial activity of endophytic fungi isolated from Sceletium tortuosum L. (Kougoed). Ann Microbiol 2019, 69, 659-663, https://doi.org/10.1007/s13213-019-1444-5.

26. Kumar, A.; Asthana, M.; Gupta, A.; Nigam, D.; Mahajan, S. Secondary Metabolism and Antimicrobial Metabolites of Penicillium. New and Future Developments in Microbial Biotechnology and BioengineeringPenicillum System Properties and Applications 2018, 47-68, https://doi.org/10.1016/B978-0-444-635013.00003-X.

27. Uzma, F.; Mohan, C.D.; Hashem, A.; Konappa, N.M.; Rangappa, S.; Kamath, P.V.; Singh, B.P.; Mudili, V.; Gupta, V.K.; Siddaiah, C.N.; Chowdappa, S.; Alqarawi, A.A.; Abd-Allah, E.F. Endophytic Fungi-Alternative Sources of Cytotoxic Compounds: A Review. Front. Pharmacol. 2018, https://doi.org/10.3389/fphar.2018.00309. 28. Xie, S.; Zhou, J. Harnessing plant biodiversity for the discovery of novel anticancer drugs targeting microtubules. Front. Plant Sci. 2017, 8, 720. https://doi.org/10.3389/fpls.2017.00720.

29. Selim, K.A.; Elkhateeb, W.A.; Tawila, A.M.; El-Beih, A.A.; Abdel-Rahman, T.M.; El-Diwany, A.I.; Ahmed, E.F. Antiviral and Antioxidant Potential of Fungal Endophytes of Egyptian Medicinal Plants. Fermentation 2018, 4, https://doi.org/10.3390/fermentation4030049.

30. Syed, A. Study of antidiabetic activities of endophytic fungi isolated from plants. Pure and Applied Biology 2019, 8, 1287-1295, https://doi.org/10.19045/bspab.2019.80071.

31. Takahashi, J.; Sande, D.; Lima, G.; Moura, M.; Nogueira, S.L.; Matheus, T. Fungal Metabolites as Promising New Drug Leads for the Treatment of Alzheimer's Disease. Studies in Natural Products Chemistry 2019, 62, 139, https://doi.org/10.1016/B978-0-444-64185-4.00001-0. 
32. Nicoletti, A.; Bartoloni, A.; Sofia, V.; Mantella, A.; Nsengiyumva, G.; Frescaline, G.; Preux, P.M. Epilepsy and Toxocariasis: A Case-Control Study in Burundi. Epilepsia 2007, 48, 894-899, https://doi.org/10.1111/j.15281167.2007.01104.x.

33. Toghueo, R.M.K. Anti-leishmanial and Anti-inflammatory Agents from Endophytes: A Review. Nat. Prod. Bioprospect. 2019, 9, 311-328, https://doi.org/10.1007/s13659-019-00220-5.

34. Khan, A.M.; Bhadauria, S. Analysis of medicinally important phytocompounds from Argemone mexicana. J. King Saud Univ.-Sci 2019, 31, 1020-1026, https://doi.org/10.1016/j.jksus.2018.05.009. 